\title{
Livvinkarjalan ymmärtämisen strategioita
}

\author{
PIRKKO MUIKKU-WERNER, \\ HELKA RIIONHEIMO \\ Itä-Suomen yliopisto
}

Tiivistelmä. Reseptiivisen monikielisyyden tutkimus on osoittanut monien kieliperheiden avulla, että kun lukija kohtaa lähisukukielisen tekstin, ymmärtäminen lähtee liikkeelle äidinkielen pohjalta tunnistettavista sanoista. Sukukielet ovat kuitenkin kehittyneet omiin suuntiinsa ja voineet esimerkiksi saada erilaista lainasanastoa. Tämän vuoksi pelkkä samankaltaisuuteen nojaaminen ei riitä tekstin ymmärtämiseksi, vaan tarvitaan myös muunlaista päättelyä. Tässä artikkelissa esitellään niitä kognitiivisia strategioita, joita 60 suomenkielistä opiskelijaa on hyödyntänyt kääntäessään suomeksi livvinkarjalaista tekstiä. Tarkasteltavana artikkelissa on yksi virke, joka sisältää ymmärtämistä vaikeuttavia venäläisiä lainasanoja.

Opiskelijat ovat tehtävässä sekä kääntäneet tekstin suomeksi että kuvailleet käännös- ja ajatteluprosessiaan, ja näiden perusteluiden avulla on mahdollista päästä kiinni heidän tietoisesti käyttämiinsä ymmärtämisstrategioihin. Aineiston analyysi osoittaa, että kääntäessään opiskelijat ovat nojautuneet karjalan ja suomen samanlaisen sanaston ohella myös monentasoiseen metalingvistiseen tietoon. Lisäksi päättelyssä on otettu huomioon virke- ja tekstikonteksti samoin kuin laajemmin tekstin aihe ja siihen liittyvä maailmantieto. Erilaiset strategiat näyttävät toimivan ymmärtämisessä samanaikaisesti ja tukevan toisiaan.

Tulosten vertailukohteena on suomen ja viron ymmärtämisessä käytetyistä strategioista tehty aiempi tutkimus. Lisäksi 
pohditaan tulosten sovellettavuutta käytäntöön: olisiko ymmärtämisstrategioihin ja päättelykeinoihin perehdyttämisestä hyötyä sukukielen opettamisessa?

Avainsanat: reseptiivinen monikielisyys; kielisukulaisuus; kääntäminen; leksikaalinen päättely

\section{Johdanto}

Tässä artikkelissa käsittelemme strategioita, joita suomalaiset kertovat käyttäneensä kääntäessään läheisellä sukukielellä livvinkarjalalla kirjoitettua tekstiä suomeksi. Rajaamme käsittelyn yhden virkkeen yhteydessä mainittuihin ratkaisuihin. Lähestymistapamme sijoittuu reseptiivisen monikielisyyden (RM) tutkimuskenttään, jossa tutkitaan ihmisten kykyä ymmärtää sukukieltä ensisijaisesti äidinkielensä avulla sekä käyttää tätä kykyä hyväkseen monikielisessä vuorovaikutuksessa (aiheesta enemmän ks. esim. Zeevaert \& ten Thije 2007). Ymmärrettävyys nojaa tällöin pitkälti kuulijan tai lukijan äidinkielen ja vieraan kielen väliseen samankaltaisuuteen. Itämerensuomalaisessa kieliperheessä reseptiivistä monikielisyyttä on tähän mennessä tutkittu etenkin suurimpien itämerensuomalaisten kielten eli suomen ja viron välillä (esim. Kaivapalu 2005; Kaivapalu \& Muikku-Werner 2010; Muikku-Werner 2013; Härmävaara 2013, 2014; Tuomainen 2017). Viime vuosina tutkimusta on kuitenkin ulotettu myös suomen ja karjalan varieteettien välille: Alekseeva (2016) on pro gradu -tutkielmassaan tutkinut suomen ja vienankarjalan välistä ymmärrettävyyttä, ja Muikku-Werner ja Riionheimo (2018) ovat suunnanneet huomion livvinkarjalalaan.

Tarkastelemme eräänlaista pulmatehtävän ratkaisemista: millaisin keinoin suomenkieliset opiskelijat ovat ratkoneet livvinkarjalaisen tekstin arvoitusta ilman että heillä on käytössä erillisiä apuneuvoja kuten sanakirjoja. Karjalan kielen ymmärtäminen nojaa hyvin vahvasti niihin samankaltaisuuksiin, jotka ovat olemassa karjalan ja suomen välillä (samankaltaisuuksista ks. tarkemmin Muikku-Werner \& Riionheimo 2018). Tekstin tulkintaa auttavat sellaiset tapaukset, joissa 
merkitykseltään samanlaiset tai läheiset karjalan ja suomen sanat muistuttavat toisiaan myös äänteellisesti. Tutkimuksissa on kuitenkin osoitettu, että myös sukukielten väliset morfologiset ja syntaktiset vastaavuudet tukevat merkitysten päättelyä (ks. esim. Rehbein ym. 2012: 250).

Kieltenvälinen samankaltaisuus ei kuitenkaan aina riitä lähisukukielisen tekstin ymmärtämiseen, sillä edes läheisten sukukielten sanasto tai morfologis-syntaktinen rakenne ei ole kaikilta osiltaan yhtenevä. Merkitysten selvittämiseen tarvitaan siten myös muita strategioita. Aiemmat vironkielisen tekstin suomeksi kääntämisen ongelmia koskevat tutkimukset (ks. esim. Kaivapalu \& Martin 2007, 2014; Kaivapalu \& Muikku-Werner 2010: 83-84; Kaivapalu 2015; Muikku-Werner 2016: 332; Muikku-Werner 2017: 214) osoittavat, että ymmärtäminen nojautuu kieltenvälisen samankaltaisuuteen lisäksi myös tietoon kielen rakenteista, käsityksiin tekstin kohesiivisuudesta ja koherenttiudesta, maailmantietoon ja kaiken edellä mainitun varassa tapahtuvaan loogiseen päättelyyn. Tällainen järkeen käyvän sisällön etsiminen sisältää niin sanottua leksikaalista päättelyä (lexical inferencing, ks. esim. Oxford 1990: 47; Muikku-Werner 2017: 203-205), jossa sanan tai ilmauksen merkitys ikään kuin luetaan rivien välistä. Leksikaaliseen päättelyyn ovat sisällytettävissä kaikki ne kielelliset ja ei-kielelliset vihjeet, joiden avulla on mahdollista ratkaista tuntemattomien sanojen aiheuttamat ongelmat.

Artikkelissa analysoimme sitä, millä tavoin livvinkarjalaista tekstiä suomeksi kääntäneet opiskelijat perustelevat tekemiään käännösratkaisuja. Emme tarkastele heidän käännöksiään emmekä niiden oikeaan osuvuutta tai virheellisyyttä, vaan olemme kiinnostuneita siitä, millaisia kääntämisen tai tekstin ymmärtämisen strategioita opiskelijat itse nostavat esille. Aiemman tutkimuksen (Muikku-Werner \& Riionheimo 2018) perusteella tiedämme, että opiskelijat ovat hyödyntäneet käännöksissään monenlaisia keinoja, ja tässä syvennämme niiden tarkastelua suuremman aineiston avulla (luvut 3 ja 4). Tavoitteena on myös selvittää suuntaa antavasti, mitkä ovat erilaisten strategioiden määrälliset suhteet (luku 5). Lopuksi kokoamme keskeiset havainnot yhteen ja pohdimme niitä myös kielenopetuksen näkökulmasta (luku 6). 


\section{Tutkimusmenetelmä ja -aineisto}

Livvinkarjalaisen tekstin ymmärtämistä testattiin käännöstehtävällä, jossa osallistujien piti kääntää suomeksi lyhyt teksti ja perustella, miten he olivat päätyneet valitsemaansa käännökseen. Testi toteutettiin kahdelle opiskelijaryhmälle verkkolomakkeella kotitehtävänä, jolloin jokainen sai käyttää sen verran aikaa kuin itse halusi. Tehtävässä ohjeistettiin lukemaan ensin teksti läpi huolellisesti ja muodostamaan siitä yleiskuva. Sen jälkeen teksti piti kääntää virke kerrallaan suomeksi ja kuvailla jokaisen virkkeen jälkeen käännökseen johtanutta ajatus- ja päättelyprosessia. Testiasetelmassa sovellettiin niin sanottua ääneenajattelumenetelmää (engl. think aloud protocol) (Boren \& Ramey 2000: 261), jossa vastaajat kertovat suullisesti kääntämisen herättämistä ajatuksista ja jota on käytetty käännösprosessitutkimuksessa (ks. esim. Jääskeläinen 1999; Bernardini 2001). Varsinainen tehtävän kanssa samanaikaisesti toteutettu ääneenajattelu pyrkii tuomaan näkyville sellaisia (ehkä tiedostamattomia) ajatusprosesseja, joista on muulla tavoin vaikea saada tietoa. Ääneenajattelumenetelmää on sovellettu myös RM-tutkimuksessa, mutta sen toteuttaminen on osoittautunut haastavaksi muun muassa siksi, että koehenkilöt eivät välttämättä ole puhuneet prosessin aikana kovinkaan paljon (ks. esim. Alekseeva 2016: 47; Tuomainen 2017: 20). Omassa tehtävässämme perustelut esitettiin kirjoittamalla sen jälkeen, kun virkkeen käännös oli ensin valmistunut. Tällaisena tehtävä tuotti runsaasti vastauksia, mutta on huomattava, että viiveellä toteutettuna menetelmä todennäköisesti tavoittaa lähinnä sellaisia käännösprosesseja, joista opiskelijat ovat olleet tietoisia.

Käännöstehtävä teetettiin Itä-Suomen yliopistossa kahdelle ensimmäisen vuoden suomen kielen opiskelijoista koostuvalle ryhmälle vuosina 2017 ja 2018. Kaikkiaan tehtävään osallistui 60 sellaista opiskelijaa, jotka antoivat luvan käyttää vastauksiaan tutkimusaineistona ja joiden äidinkieli oli suomi (34 opiskelijaa vuonna 2017 ja 26 opiskelijaa vuonna 2018). Suurin osa osallistujista oli yliopistoon juuri tulleita uusia opiskelijoita, mutta joukossa oli myös suomen kielen sivuaineopiskelijoita, 
joilla oli aiempia yliopisto-opintoja eri aineissa. Juuri kenelläkään ei ollut kosketuksia karjalan kieleen, mutta muutama mainitsi kuulleensa karjalasta joko lukion äidinkielentunneilla tai aiemmissa yliopisto-opinnoissaan tai tuntevansa karjalan kielen puhujia. Osalla opiskelijoista oli karjalaisia sukujuuria, mutta karjalan kielestä oli heilläkin suvun piirissä jäljellä korkeintaan joitain sanoja tai sanontoja. Jotkut vastaajista olivat opiskelleet venäjää, mikä saattaa edistää karjalassa yleisten venäläisten lainasanojen tunnistamista (ks. Muikku-Werner \& Riionheimo 2018: 306). Tehtävä ajoitettiin heti syyslukukauden alkuun, jolloin opiskelijoilla ei vielä ollut suomen kielen opintojen antamaa kielitietoa. Vastaukset kuitenkin osoittavat, että osa heistä pystyi käyttämään metalingvististä tietoa käännöstehtävän ratkaisussa. Tätä tietoa heille on todennäköisesti kertynyt äidinkielen ja vieraiden kielten opiskelusta koulussa ja sivuaineopiskelijoilla aikaisemmista yliopistotasoisista kieliopinnoista.

Käännettävänä oli teksti, joka on luettu Ylen karjalankielisessä uutislähetyksessä 11.11.2016 (ks. liitettä 1). Uutinen käsittelee kilpailukykysopimusta ja siihen liittyvää työajan pidennystä, joka oli aiheena ajankohtainen myös vuosina 2017 ja 2018. Tekstissä kerrotaan pohjoiskarjalaisen Juuan kunnan ehdotuksesta, että päivittäiseen työaikaan lisättävät kuusi minuuttia käytettäisiin työpaikkaliikuntaan. Tässä artikkelissa valitsimme tarkasteltavaksi seuraavan, tekstin keskellä olleen virkkeen:

Kilbumaltosobimuksen mugah päivän ruadoaigu roih kuuttu minuuttua pitkembi, da muga ruadonedäli roih puoldu čuassuu pitkembi. 'Kilpailukykysopimuksen mukaan työaika pitenee kuusi minuuttia päivässä eli puoli tuntia viikossa.'

On siis huomattava, että tämän virkkeen kääntämistä perustellessaan opiskelijat olivat jo kirjoittaneet perustelut kolmen edeltävän virkkeen käännökseen. Käännösratkaisujen pituus oli hyvin vaihteleva: lyhyimmillään sana tai pari, pisimmillään useiden virkkeiden mittainen perusteellinen kuvaus. 
Vastauksissaan moni opiskelija kommentoi nimenomaan tämän virkkeen kääntämisen vaikeutta, ja monet jättivät osan tai osia virkkeestä kokonaan kääntämättä. Virke sisältää useita suomalaisille haastavia elementtejä. Pitkä yhdyssana kilbumaltosobimus 'kilpailukykysopimus' on vaikea hahmottaa (livvinkarjalan yhdyssanojen kääntämisestä ks. myös Muikku-Werner \& Riionheimo 2018: 297-298), ja venäläiset lainasanat nedäli 'viikko' ja čuassu 'tunti' ovat suomen kielen näkökulmasta läpinäkymättömiä. Lisäksi virke sisältää kaksi kertaa suomelle vieraan roita-verbin ('tulla, tapahtua'), jota on taivutettu livvinkarjalan refleksiivitaivutuksen mukaisesti. Tällöin yksikön 3. persoonan (futuurissävyinen) preesens on $h$-loppuinen (roih) eikä sen vuoksi muistuta mitään suomen verbien taivutusmuotoa.

Valittu virke tarjoaa siis mahdollisuuden tarkastella myös sitä, miten opiskelijat ovat toimineet silloin, kun suomen ja karjalan äänteellinen samankaltaisuus ei ole auttanut ymmärtämistä. Analyysin kautta pyrimme pääsemään kiinni opiskelijoiden hyödyntämiin ymmärtämisstrategioihin. Strategialla tarkoitamme tässä suunnitelmallista menettelyä, jota opiskelijat ovat käyttäneet tietoisesti ymmärtääkseen lukemaansa tekstiä. Oxford (2011) toteaa, että yleensä nämä ymmärtämistekniikat ovat ongelmapainotteisia. Ne ovat myös päämäärähakuisia, ja ne voivat olla tietoisia, alitajuisia tai automaattistuneita (Anastasiou \& Griva 2009). Tehtävänannossa opiskelijoille asetettiin tavoitteeksi kielentää käännösehdotuksensa perustelut, joten tehtävää pohtiessaan he ovat suurelta osin kuvanneet nimenomaan tietoisesti käytettyjä strategioita. On muistettava, että mikä tahansa strategia voi johtaa paitsi oikean käännösvastineen löytämiseen myös virheelliseen lopputulokseen: esimerkiksi samankaltaisuuteen nojaavan päättelyn pohjalta opiskelijat ovat saattaneet kääntää karjalan sanan ruadoaigu oikein 'työajaksi' mutta myös väärin 'ruoka-ajaksi'. Tämän artikkelin näkökulmasta ei käännöksen onnistuneisuudella ole kuitenkaan merkitystä, sillä keskitymme kuvaamaan strategioita toimintatapoina.

Analyysimme on ensisijaisesti laadullista eli pyrkii luokittelemaan raportoitujen strategioiden erilaisia tyyppejä, mutta lisäksi 
tarkastelemme myös strategioiden määrällisiä suhteita. Strategiat jakautuvat kahteen suurempaan ryhmään: yhtäältä nojaudutaan karjalan ja suomen (osittain myös eräiden muiden kielten) väliseen samankaltaisuuteen niin leksikaalisella kuin kieliopillisellakin tasolla, ja toisaalta esiin nousee leksikaalinen päättely, joka pohjautuu virke- tai tekstikontekstiin ja opiskelijan yleis- tai maailmantietoon (ks. myös Babashamsi ym. 2013). Seuraavissa luvuissa tarkastelemme ensin samankaltaisuutta ja sen jälkeen kontekstia ja yleistietoa hyödyntäviä strategioita.

\section{Kieltenväliseen samankaltaisuuteen perustuvat strategiat}

Livvinkarjalan käännöstehtävän perusteluissa opiskelijat kertovat nojanneensa karjalan sanojen tai taivutusmuotojen samankaltaisuuteen suomen kanssa. Vastauksissa on välillä eksplisiittisesti mainittu yhtäläisyydet suomen kielen kanssa (1a-1b), mutta samaan ryhmään olemme luokitelleet myös ne perustelut, joissa puhutaan yleisemmällä tasolla sanojen tuttuudesta tai samanlaisuudesta mainitsematta suomen kieltä nimeltä (1c-1e; tekstin jälkeinen O-alkuinen koodi viittaa siihen opiskelijaan, joka on kyseisen perustelun kirjoittanut). Vastauksissa toistuvat sellaiset sanat kuin sama, samanlainen, muistuttaa, kuulostaa, tuttu ja tuttuus, jotka nekin viittaavat yhtäläisyyksien hakemiseen.

(1a) Ensimmäinen lause [tarkoittanee kyseisen virkkeen ensimmäistä lausetta] on helposti tulkittavissa, sillä suurin osa sanoista muistuttaa (suomen) yleiskielisiä vastineitaan. (O8)

(1b) Sanan "roih" käänsin "noin", sillä sanan kirjaimet ovat ulkoasultaan hieman samankaltaiset. (O38)

(1c) Muuten käännös oli helppoa samanoloisten sanojen takia. (O9)

(1d) Päättelin sanat tuttuuden perustella. (O10)

(1e) Sanat, mitkä pystyin kääntämään olivat tunnistettavissa useiden samojen kirjaimien takia. (O49)

Aiemmassa tutkimuksessa on havaittu, että vironkielisen tekstin ymmärtämispyrkimyksissä suomalaiset nojautuvat äidinkielen lisäksi 
myös samankaltaisuuksiin muiden osaamiensa kielten kanssa (MuikkuWerner \& Heinonen 2012: 179; Paajanen \& Muikku-Werner 2012: 238; Muikku-Werner 2016: 238; Muikku-Werner \& Riionheimo 2018: 306). Myös meidän aineistossamme muutamat vastaajat hyödynsivät karjalan ja eräiden muiden kielten välistä äänteellistä samankaltaisuutta. Esimerkissä 2a opiskelija on ensin segmentoinut yhdyssanan ruadonedäli 'työviikko' väärin ajatellen, että jälkiosana on edäli, mutta siitä huolimatta hänen mieleensä tulee viron viikkoa tarkoittava sana nädal. Toinen opiskelija taas on venäjäntaitoisena yhdistänyt karjalan nedälin venäjän sanaan неделя 'viikko' (2b), ja kyseessä onkin venäläinen lainasana sekä karjalassa että virossa. Venäjän avulla vastauksessa $2 \mathrm{~b}$ on niin ikään havaittu, että karjalan čuassu on äänteellisesti lähellä venäjän sanaa uac 'tunti'. Nämä päättelyt ovat kiinnostavia, sillä vaikka nedäli ja čuassu ovat karjalassa melko vanhoja ja äänteellisesti mukautuneita lainoja, silti niiden yhteys venäjään on ollut tunnistettavissa.

(2a) Ruadonedäli oli vaikea, sillä vaikka ruadon olen omalla logiikallani päätellyt olevan työ, niin edäli ei soitellut kelloja. Edäliä kuitenkin miettiessä aloin jostain kumman syystä muistelemaan viron viikkosanaa (nädal) ja päässäni se kytkeytyi viikoksi. (O17)

(2b) Karjalan sana muistuttaa venäjän sanaa "nedelja" = viikko. "tuntia": Karjalan sana muistuttaa venäjän sanaa "chas" = tunti. $(\mathrm{O} 43)$

Äänteellisten samankaltaisuuksien etsimiseen voidaan liittää myös ääneen lukemisen strategia, joka on useissa aikaisemmissa itämerensuomalaisten kielten reseptiivistä monikielisyyttä käsittelevissä tutkimuksissa todettu keinoksi lisätä vieraiden sanojen tunnistettavuutta (ks. esim. Kaivapalu \& Muikku-Werner 2010: 83; Paajanen \& MuikkuWerner 2012: 241). Suomen ja karjalan samoin kuin suomen ja viron välillä on jonkin verran ortografisia eroja, ja ero kahden erilaisen grafeemin välillä voi olla havaitsemisessa suurempi kuin niitä vastaavien äänteiden välinen ero. Viron ymmärtämisen tutkimuksessa on havaittu, että jos testihenkilöt kuulivat viron sanat puhuttuina, niiden yhteys suomenkielisiin vastineisiin hahmottui helpommin kuin niillä testihenkilöillä, jotka näkivät vironkieliset sanat tekstinä (Heinonen 2015: 58; 
kuitenkin toisenlaisista testituloksista ks. Härmävaara ja Gooskens tässä numerossa). Myös meidän aineistossamme on tapauksia, joissa opiskelijat kertovat lukeneensa tehtävää tehdessään lähtötekstiä ääneen (ks. 3a-3b). Sen lisäksi, että ääneen lukeminen auttoi tunnistamaan karjalan ja suomen välisiä yhtäläisyyksiä, siitä on ollut apua myös karjalan kielen venäläislainojen tunnistamisessa (3c).

(3a) Mugah-sana vaikutti sekä luettuna, että ääneenlausuttuna sanalta mukaan. (O5)

(3b) Muut sanat käänsin sana kerrallaan kuullun perusteella. (O31)

(3c) Venäjän opinnoistani on jo muutama vuosi aikaa, mutta sanomalla sanat ääneen ne muistuttivat venäjäläisiä sanoja ja ulkomuodossakin oli samankaltaisuuksia. (O42)

Tehtävään osallistuneet opiskelijat hyödynsivät kääntäessään paitsi leksikaalista samankaltaisuutta myös metalingvististä tietoa eli tietoa kielen rakenteesta ja kielen kuvaamiseen käytettäviä kielitieteellisiä käsitteitä (vastaavista tuloksista suomen ja viron välillä ks. esim. Kaivapalu \& Muikku-Werner 2010: 86-87; Kaivapalu 2015: 63). Myös livvinkarjalaisen tekstin ymmärtämisessä on paljon apua siitä, että suomen ja karjalan morfologia ja syntaksi ovat suhteellisen samanlaiset (Muikku-Werner \& Riionheimo 2018: 295-304). On todennäköistä, että kielen rakenteiden taju on ollut apuna karjalankielisen tekstin tulkinnassa myös tiedostamattomana keinona, mutta eräissä perusteluissa metalingvistisen tiedon hyödyntämistä on kuvattu eksplisiittisesti. Esimerkeissä 4a-4b opiskelija soveltaa suomen kielen äänne- ja muotorakennetta koskevaa tietoaan kuvaillessaan, miten karjalankieliset sananmuodot eroavat suomesta. Tämä tieto ei ole ollut välttämätöntä kyseisten sanojen ymmärtämiseksi, mutta se kertoo kyvystä soveltaa opittuja käsitteellisiä työvälineitä. Koska on kyse aloittelevien suomen kielen opiskelijoiden ryhmästä, useimmissa vastauksissa käytetään kuitenkin vähän tai ei ollenkaan kielitieteellistä terminologiaa, ja karjalan ja suomen välisiä eroja kuvataan epämääräisemmin (ks. 4c). 
(4a) [Karj. mugah] "mukaan": g/k vaihtelu ja illatiivin pääte -h. (O43)

(4b) [Karj. pitkembi] "pitempi": pitkä -> + komparatiivin tunnus -mbi (jossa b/p vaihtelu), se vaikutti siihen, että sanan ä:stä tuli e. (O43)

(4c) "Kuuttu" on kuusi ja "minuuttua" minuuttia. Vokaalit vain ovat "väärin" noissa sanoissa. (O18)

Virkkeessä kahdesti esiintyä roih-verbimuoto oli opiskelijoille vieras, ja koska sen läpinäkymättömyys on vaikeuttanut kääntämistä, se on samalla pakottanut osallistujat kiinnittämään huomiota virkekokonaisuuteen (ks. myös Muikku-Werner \& Riionheimo 2018: 303). Esimerkit $5 a-5 b$ osoittavat, että vaikka virkkeen kaikkia sanoja ei ymmärtäisikään, ainakin kielen rakennetta tuntevan lukijan on helppo nähdä, että roih on virkkeessä predikaatin paikalla.

(5a) Roih-sana tuotti vaikeuksia, koska se ei kuulosta tutulta, mutta lausetta lukiessani päädyin sen olevan joko jonkin sortin täytesana tai määre (kuten enkun The/a/an tai ruotsin en/ett), tai sitten olevan onverbi hyvin oudossa muodossa (ainakin itselle). Lauseeseen nähden on-verbi vaikutti luonnollisimmalta, joten päädyin siihen. (O17)

(5b) Roih vois olla noin, mutta ei sovi käännöksee, joten on, koska muuten verbi puuttuu. (O19)

Tässä luvussa esitellyt samankaltaisuuden ympärille kietoutuvat ymmärtämisen keinot näyttävät olleen opiskelijoiden perusstrategioita. Muutamassa vastauksessa viitattiinkin siihen, että kyseessä on läpi koko käännöstehtävän sovellettu strategia (6a-6b). Mielenkiintoisia ovat myös ne kaksi perustelua, joissa tuodaan esille samankaltaisuuteen perustuvan strategian toimimattomuus tämän virkkeen käännöksessä (6c-6d). Kaikki tehtävään osallistuneet opiskelijat ovat tätä virkettä kääntäessään kohdanneet sen ongelman, että eräillä karjalan kielen sanoilla ei ole suomessa äänteellisesti läheistä vastinetta, ja näissä tapauksissa samankaltaisuuteen nojaava strategia ei toimi. Seuraavassa luvussa käsittelemme niitä keinoja, joita opiskelijat ovat näissä tapauksissa käyttäneet.

(6a) Yritin toimia samalla logiikalla kuin aikaisemmissa kohdissa, eli etsimällä tutun kuuloisia sanoja. $(\mathrm{O} 20)$ 
(6b) Toki esimerkiksi ajalliset määreet ovat melko lähellä suomen kieltä, joten taas aloitin miettimään mitä voisin päätellä äidinkielestäni. (O44)

(6c) Vaikea lause, oli useampi sana jotka ei muistuttanut mitään järkevää suomen kielen sanaa ja vaikka muistuttikin ei käynyt tai sopinut asiayhteyteen/lauseeseen. (O23)

(6d) Useita sanoja jäi kääntämättä, koska minulle ei tullut mieleen niistä suomen kielistä vastiketta. (V49)

\section{Kontekstiin ja yleistietoon perustuvat strategiat}

Edellisen luvun esimerkeistä näkyy hyvin, miten keskeinen strategia samankaltaisuus on käännettävän virkkeen sanojen tunnistamisessa. Aiempi tutkimus on osoittanut, että toisiaan muistuttavia sanojen vähyys tai puuttuminen tekee sukulaiskielen kääntämisestä vaikeaa. Jos yhdenkin keskeisessä asemassa olevan sanan merkitys jää selvittämättä, koko tekstiä ei ehkä ymmärretä (van Beezoijen \& Gooskens 2007: 258). Livvinkarjalankielisen uutistekstin tarkasteltava virke sisältää useita sanoja, joilla ei ole äänteellistä yhteyttä suomenkielisiin käännösvastineisiinsa, ja tämä on pakottanut opiskelijat kokeilemaan myös muunlaisia ymmärtämisen keinoja. Niille on yhteistä se, että opiskelijat eivät prosessoi lukemaansa karjalankielistä tekstiä sana kerrallaan vaan tarkastelevat uutista myös laajempana kokonaisuutena.

Suppeimmillaan konteksti tarkoittaa virkekontekstia, jota opiskelijat ovat käyttäneet koulujen äidinkielenopetuksesta tuttua nimitystä "lauseyhteys”. Esimerkissä 7a opiskelija perustelee käännösratkaisuaan sillä, että valitut suomenkieliset sanat sopivat virkekontekstiin. Esimerkki 7b taas osoittaa, että virkekonteksti on voinut ohjata opiskelijaa päättelemään oikean käännösvastineen, vaikka karjalan sana on aivan erilainen kuin sen suomenkielinen vastine.

(7a) Loppu on todella hankala, enkä saa siitä oikein mitään järkevää lausetta, mutta jotenkin lauseyhteyteen sopisi ehkä tällainen. (O13) 
(7b) Sana čuassuu oli vaikea, koska se ei muistuta mitään suomen kielen sanaa omasta mielestäni. Vaikkeivät ne muistuta ulkonäöltään toisiansa, niin lauseyhteyteen nähden tunti sopii siihen mainiosti. (O17)

Karjalankielisen uutisen kääntämistä on vahvasti ohjannut tekstikonteksti ja kehotus lukea koko teksti useampaan kertaan ennen virkkeiden kääntämistä. Tehtävään osallistuneet opiskelijat ovat käyneet suomalaisen lukion, jonka äidinkielen ja kirjallisuuden opetuksessa tekstitaitojen rooli on nykyään korostunut. Opiskelijat siis tietävät, että tekstit ovat temaattisesti koherentteja ja kielellisesti kohesiivisia kokonaisuuksia, joissa elementit ovat sidoksissa toisiinsa ja muodostavat eheän, yhtenäisen kokonaisuuden. Livvinkarjalaisen uutistekstin odotetaan olevan temaattisesti johdonmukainen, mikä vaikuttaa myös käännöksen laatuun. Useiden opiskelijoiden vastauksissa on mainintoja siitä, että käännösvastineita pohdittaessa on huomiota kiinnitetty tekstikokonaisuuteen (ks. esimerkkejä 8a-8c). Perusteluissa mainitaan usein termit "konteksti" ja "asiayhteys", jotka ovat opiskelijoille kouluopetuksesta tuttuja.

(8a) Päättelin sanojen osista ja tekstin kokonaissisällöstä suomenkielisen version. (O7)

(8b) Ainoastaan sanan "roih" tulkinta perustuu puhtaasti asiayhteyteen pohjautuvaan arvaukseen. (O8)

(8c) Kaikkia sanoja en ymmärtänyt, kuten "cuassuu” tai "roih", mutta arvelisin kontekstin perusteella, että sivulauseessa puhutaan työajan viikottaisesta pidennyksestä. (O18)

Silloin kun karjalankieliset sanat eivät muistuta suomea, niiden käännösvastineiden valinta vaatii leksikaalista päättelyä, joka sisältää kaiken tekstissä annetun informaation prosessointia (ks. esim. O’Malley \& Chamot 1990; Bernhardt 1991; Vaurio 1998: 41-44). Uutiskontekstissa aiemmin tunnistetut, suomelle läheisemmät sanat rajaavat käännösvastineiksi tarjoutuvien sanojen joukkoa, sillä uusi informaatio pyritään kytkemään jo esitettyyn (ks. myös Oxford 1990: 41). Aineistosta voidaan tässä yhteydessä nostaa erityisesti esille livvinkarjalan kolmiosainen yhdyssana kilbumaltosobimus 'kilpailukykysopimus', jonka keskimmäinen sana 
malto on suomalaisille vieras. Yhdyssanan alkupuoli on ollut vaikea hahmottaa, ja osa opiskelijoista on lähestynyt sanan merkitystä tekstikontekstin avulla pyrkien käännökseen, joka olisi kokonaisuuden kannalta luonteva (9a-9b). Suomalaisille vaikeita ovat olleet myös ruadoaigu 'työaika' ja ruadonedäli 'työviikko', joista jälkimmäiseen sisältyy venäläinen lainasana. Nämä ovat tuottaneet tehtävässä pulmia (ks. myös MuikkuWerner \& Riionheimo 2018: 305), mutta osa opiskelijoista on käyttänyt tekstikontekstia apuna käännösvastineiden etsimisessä (9c-9d).

(9a) Kontekstista päättelin ensimmäisen sanan tarkoittavan kilpailukykysopimusta vaikka koko sanaa en ymmärtänytkään alkuperäisestä tekstistä. (O29)

(9b) Kilbumaltosobimus kuulostaa kilpailutussopimukselle, ja se tuntuu sopivan myös tekstin kontekstiin. (O46)

(9c) Sanan "ruadoaigu" ymmärsin aiemman virkkeen kontekstin ja koko tekstin perusteella. (O34)

(9d) Jälleen ruodo-alkuiset sanat olivat hankalia, mutta käänsin ne jälleen sen mukaan, mistä minusta tekstissä vaikutti olevan kokonaisuudessaan kyse. (O60)

Tekstikontekstin lisäksi luetun ymmärtäminen nojautuu vieläkin laajemmin niin sanottuun maailmantietoon eli kaikkeen yksilön elämänsä aikana omaksumaan ja oppimaan tietoon siitä, miten maailman asiat ja ilmiöt toimivat (ks. esim. Ringbom 2007: 15). Tällaisen taustainformaation aktivoituminen auttaa myös tekemään oletuksia tuntemattoman sanan merkityksestä, tai ainakin siitä on hyötyä oletusten vahvistamisessa (Vaurio 1998: 60). Käännöstestissä käytetty uutinen sijoittuu Suomeen ja ajoittuu tiettyyn yhteiskunnalliseen tilanteeseen eli pääministeri Sipilän hallituksen toteuttamaan kilpailukykysopimuksen nimellä tunnettuun työehtosopimukseen. Nuorten aikuisten ajankohtainen tieto julkisuudessa paljon keskustellusta sopimuksesta on olennaisesti auttanut käännöstehtävän tekijöitä silloin, kun he ovat osanneet yhdistää uutisen nimenomaan kilpailukykysopimukseen. Osa opiskelijoista tuokin yhteiskunnallisen tietämyksen merkityksen esiin vastauksissaan. Esimerkit 10a-10b osoittavat, että aihepiirin tunnistaminen on vahvasti 
ohjannut oikean vastineen löytämistä. Esimerkki 10c puolestaan osoittaa, että vaikka kilpailukykysopimus jäisi tunnistamatta, opiskelija on silti etsinyt suomenkielistä vastinetta ajankohtaisesta kontekstista ja tarjoaa yhdeksi vaihtoehdoksi ilmastosopimusta (Pariisin ilmastosopimus vuodelta 2015 on ollut käännöstä tehtäessä edelleen ajankohtainen ja esillä uutisissa).

(10a) Työehtosopimuksen tuntemusta hyödyntäen päättelin tämänkin ja käänsin virkkeen mielestäni järkevimpään muotoon. (O6)

(10b) Tähän käännökseen jouduin käyttämään apuna koko tekstiä, sekä aiempaa jo opittua yhteiskunnallista tietoa. Tekstin perusteella kyse voisi olla juuri kilpailukyky sopimuksesta. (O44)

(10c) "kilbumaltosobimuksen" tarkoittaa varmasti jotain sopimusta, esimerkiksi kilpailusopimusta tai ilmastosopimusta. Yhtä hyvin se voi tarkoittaa jotain muuta sopimusta. (O47)

Maailmantiedon ja aikaisemmin opitun tiedon piiriin voidaan lukea myös yhteenlaskutaito ja tieto ajan yksiköiden ilmaisemisesta. Tarkasteltavassa virkkeessä kerrotaan, että työaika pitenee päivässä kuusi minuuttia eli viikossa puoli tuntia, ja jos opiskelija on ymmärtänyt, että on kyse työviikosta eli viidestä arkipäivästä, hän päätyy laskutoimitukseen 5 x 6 . Kuten esimerkit 11a-11c osoittavat, tämän yhteenlaskun lopputulos on auttanut useita opiskelijoita selvittämään, mitä karjalan čuassu 'tunti' tarkoittaa, ja päsemään ehkä myös nedälin 'viikko' jäljille. Lisätukena tälle laskelmalle on voinut toimia myös yhteiskunnallinen tieto päivittäisen työajan kuuden minuutin pidentymisestä.

(11a) Puoldu alkoikin pian vaikuttaa puolelta ja nopeasti laskemalla $6 \mathrm{~min}$ *5(työpäivää) sain 30min joten tästä asiayhteydestä lauseen loppuosa selveni, vaikken "čuassuu" osannutkaan liittää heti tuntiin. (O3)

(11b) [---] koska jos päivässä pitää pyhittää kuusi minuuttia liikunnalle, niin eikö luonnollisesti viikossa kuudesta minuutista tule ainakin se puoli tuntia? (O17)

(11c) Aluksi etenin vain päättelemällä, että nedäli tarkoittaa luultavasti viikkoa, koska työpäivistä muodostuu työviikko ja "čuassuu" olisi 
mahdollisesti tunti, koska kuusi minuuttia päivässä muodostaa 30 minuuttia. (O42)

Lisäksi aineiston perusteluissa näkyy epämääräisemmin "(loogiseksi) päättelyksi” tai "arvaamiseksi” kuvattuja käännösstrategioita. Sanat looginen ja päätellä tai päättely näyttäisivät kuvaavan ajatusprosessia, joka etenee johdonmukaisten periaatteiden mukaisesti ja hyödyntää erilaisia vihjeitä. Päätellä-verbiä käytetäänkin perusteluissa usein siten, että samalla kerrotaan, mihin päättely perustui (esim. "päättelin suomen kielestä", "kontekstista päättelin"). Olemme kuitenkin erottaneet omaksi ryhmäkseen sellaisen päättelyksi tai loogiseksi ajatteluksi nimetyt käännösstrategiat, joissa ei eksplikoida päättelyn perusteita (12a-12c).

(12a) Roih oli edellä mainitusta pätkästä haastavin, mutta päättelin sen tarkoittavan olisi. (O5)

(12b) Yritin ajatella loogisesti. (O28)

(12c) Käänsin helpommat sanat ja käytin loogista päättelykykyä muiden sanojen kääntämiseen. (O41)

Myös sanoja arvata tai arvaus sekä veikata tai veikkaus käytetään perusteluissa, mutta näiden sanojen sisältämä sävy on hieman toisenlainen. Joskus näidenkin sanojen yhteydessä mainitaan arvaamisen tai veikkaamisen taustalla olevan perusteet ("asiayhteyteen perustuvaan arvaukseen", "veikkaukseen päädyin, sillä 6 minuuttia per päiviä on 6 x $5=30$ minuuttia per viikko"). Tavallisempaa kuitenkin on, että näitä sanoja käytetään ilman muiden strategioiden kuvailua (13a-13d). On mahdollista, että arvaukset eivät ole useinkaan olleet täysin sattumanvaraisia, mutta opiskelijat eivät ole näissä tapauksissa olleet tietoisia omasta pätttelyprosessistaan eivätkä osaa sitä kuvata. "Arvaaminen" saattaa myös olla opiskelijoiden keino ilmaista perusteluissa se, että he eivät ole varmoja käännösratkaisunsa onnistuneisuudesta. Vastaavanlaisesta keinosta on mainintoja myös suomen ja viron välisessä tutkimuksessa (Kaivapalu 2015: 67).

(13a) En ymmärtänyt lausetta ja sen merkitys jäi pimentoon. Veikkasin kuitenkin joitain sanoja, jotta saisin jotain vastattua. (O11) 
(13b) Arvailin osan sanoista, koska ne olivat hieman hankalia. (O30)

(13c) Perustuu vahvasti arvailuun, (O35)

(13d) Arvasin kaiken. (O45)

Tässä luvussa esitettyjen käännösstrategioiden perusteella on nähtävissä, että läheisen sukukielen ymmärtämisessä suppeampaan tai laajempaan kontekstiin nojautumisella on suuri merkitys. Siten edes sukukielten välinen ymmärrettävyys ei perustu pelkästään yhteiseen sanastoon. Tämä on aikaisemmin osoitettu suomen ja viron ymmärrettävyyttä käsittelevässä tutkimuksessa (Paajanen \& Muikku-Werner 2012: 251; Muikku-Werner 2013: 223-227), ja livvinkarjalan käännöstesti tukee vahvasti kontekstiin perustuvien ymmärtämisstrategioiden merkitystä.

\section{Ymmärtämisstrategioiden määrällinen jakauma}

Olemme edellä esittäneet käännöstehtävän perusteluista esiin nousevia ymmärtämisstrategioita. Vaikka artikkelin päätavoitteena on näiden ymmärtämistä tukevien keinojen laadullinen kuvaus, haluamme myös tarkastella niiden määrällistä jakaumaa. Luvuissa 3 ja 4 kuvatut strategiat on esitetty kootusti taulukossa 1, ja lukumäärät kertovat, kuinka moni opiskelija on tuonut kyseisen strategian esille käännösratkaisunsa perusteluissa. Henkilöittäinen taulukko on esitetty liitteessä 2, ja se osoittaa, miten vaihtelevasti opiskelijat raportoivat käännösprosessistaan. Osa opiskelijoista ei vastauksessaan tuonut esiin mitään selvää strategiaa, kun taas eräät mainitsivat jopa viisi tai kuusi strategiaa. Taulukkoa 1 tulkitessa on otettava huomioon, että kukin strategia on otettu laskuihin mukaan vain kerran samalta opiskelijalta, vaikka pitkissä perusteluissa saattaa sama keino tulla mainituksi useastikin. Strategioiden yleisyyden maksimäärä on siten 60 (= tehtävään osallistuneiden opiskelijoiden lukumäärä), ja prosenttiluvut kertovat, kuinka suuri osa opiskelijoista on kyseiseen strategiaan viitannut vastauksessaan. Strategiat on ryhmitelty taulukkoon samaan järjestykseen, jossa olemme niitä edellä käsitelleet. 
TAuLuкко 1. Opiskelijoiden $(N=60)$ käyttämien ymmärtämisstrategioiden yleisyys

\begin{tabular}{|l|c|c|}
\hline Strategiat & Yleisyys & $\begin{array}{c}\text { Strategian maininneiden } \\
\text { opiskelijoiden osuus }\end{array}$ \\
\hline Samankaltaisuus & 33 & $55 \%$ \\
Ääneen lukeminen & 6 & $10 \%$ \\
Muut kielet & 4 & $7 \%$ \\
Metalingvistinen tieto & 8 & $13 \%$ \\
\hline Virkekonteksti & 4 & $7 \%$ \\
Tekstikonteksti & 17 & $28 \%$ \\
Maailmantieto & 14 & $23 \%$ \\
\hline "Päättely" & 4 & $7 \%$ \\
"Arvaaminen" & 11 & $18 \%$ \\
\hline
\end{tabular}

Kieltenväliseen samankaltaisuuteen on viitannut tehtävässä vähän yli puolet opiskelijoista (mukana on myös kaksi opiskelijaa, jotka kuvasivat perusteluissa ainoastaan samankaltaisuuteen pohjautuvan strategian epäonnistumista). Muut samankaltaisuuteen kytkeytyvät strategiat (ääneen lukeminen, yhtäläisyyden muiden kielten kanssa metalingvistinen tieto) tulivat näkyviin vain muutamien opiskelijoiden vastauksissa. Koska karjalankielisen tekstin ymmärtäminen nojaa niihin sanoihin, joiden suomenkieliset vastineet ovat selvästi tunnistettavissa, lukumäärä herättelee pohtimaan, miksi vain noin puolet opiskelijoista on maininnut tämän strategian. Ehkä karjalan ja suomen välisen samankaltaisuuden hyödyntäminen on niin itsestään selvää toimintaa, ettei sitä edes mielletä ymmärtämisstrategiaksi. Osa opiskelijoista kuvasi perusteluitaan niin niukasti, ettei niistä käy selville mitään varsinaista strategiaa. Lisäksi on otettava huomioon, että tässä tarkasteltava virke oli tekstin keskellä, ja opiskelijat eivät mahdollisesti halunneet enää toistaa strategiaa, jota olivat kuvanneet jo useamman kerran.

Koska käännettävässä virkkeessä on mukana useita sanoja, jotka eivät ole tunnistettavissa suomen kielen pohjalta, perustelut paljastivat myös muunlaisten ymmärtämisstrategioiden hyödyntämistä. Virkekonteksti 
tuli esiin vain neljän opiskelijan vastauksissa, kun taas tekstikonteksti tai yleis- ja maailmantieto mainittiin selvästi useammin.

Jos katsotaan näiden strategioiden jakautumista henkilöittäin (ks. liitettä 2), on tekstikontekstin tai maailmantiedon (tai molemmat) maininnut kaikkiaan 26 opiskelijaa eli lähes puolet vastaajista. Nämä lukumäärät tuntuvat siis selvästi osoittavan, että kieltenvälisen samankaltaisuuden ohella kontekstitiedon apu on ollut kääntämisessä erittäin tärkeä.

Olemme sisällyttäneet taulukkoon myös kaksi varsin epämääräisesti kuvattua ymmärtämisstrategiaa, jotka nimeämme opiskelijoiden omia sanavalintoja heijastaen "päättelyksi" ja "arvaamiseksi”. Näihin laskelmiin on otettu mukaan vain sellaiset tapaukset, jossa päättelyn tai arvaamisen perusteita (kuten samankaltaisuutta tai tilannekontekstia) ei ole vastauksessa millään tavoin mainittu. Tällaisessa muodossa päättelyn mainitsee neljä opiskelijaa ja arvaamisen yksitoista. Oletamme, että arvaaminen ei useinkaan ole täysin sattumanvaraista vaan että kyseessä ovat ennemminkin niin sanotut valistuneet arvaukset, jotka perustuvat (ehkä tiedostamattomasti sovellettuna) joidenkin edellä kuvattujen ymmärtämisstrategioiden käyttöön. Tähän viittaa sekin, että useimmiten "arvaaminen" mainitaan sellaisissa vastauksissa, joissa on tuotu esille myös muiden strategioiden soveltamista (ks. liite 2). Vain yhden opiskelijan vastauksessa se on ainoana strategiana.

On selvää, että taulukon 1 esittämään jakaumaan täytyy suhtautua varovaisesti ja ettei siitä tehtyjä päätelmiä voi yleistää edes saman tekstin muiden virkkeiden käännöksiin. Olemme valinneet tähän artikkeliin tarkoituksellisesti sellaisen virkkeen, jossa oli suomesta poikkeavaa sanastoa ja joka toisaalta tarjosi numeerisen tiedon muodossa mahdollisuuden maailmantietoa hyödyntävään päättelyyn. Määrällinen analyysi nostaa kuitenkin esiin kontekstiin liittyvien strategioiden käyttöä. Läheisellä sukukielellä kirjoitetun tekstin ymmärtämisessä huomiota kiinnitetään usein siihen, miten paljon apua on kieltenvälisestä samankaltaisuudesta. Livvinkarjalan käännöstesti osoittaa, että samankaltaisuuden rinnalla kuitenkin kuljetetaan tekstikontekstiin ja yleiseen maailmantietoon liittyviä strategioita. 


\section{Keskustelua}

Tässä artikkelissa olemme esitelleet joukon strategioita, joiden avulla opiskelijat näyttävät - heidän tehtävään kirjaamiensa kuvausten perusteella - käyttäneen kääntäessään livvinkarjalankielistä virkettä suomeksi. On ilmeistä, että käytännössä nämä strategiat eli karjalan ja suomen välisten samankaltaisuuksien etsiminen (osittain ääneen lukemisen avulla), metalingvistisen tiedon soveltaminen, virke- ja tekstikontekstin hyödyntäminen sekä tekstinulkoisen maailmantiedon huomioon ottaminen eivät ole useinkaan selvästi toisistaan erotettavissa. Luetun ymmärtämisessä ja kääntämisessä mitä todennäköisimmin toimii useita rinnakkaisia prosesseja, jotka joskus tukevat toisiaan, joskus taas tuottavat ristiriitaisia tuloksia. Suomen ja karjalan välisten äänteellisten tai ortografisten samankaltaisuuksien hakeminen on luonnollisesti eräänlainen perusstrategia, mutta opiskelijat ottavat tekstiä tulkitessaan koko ajan huomioon myös tekstikontekstin. Silloin kun samankaltaisuuteen perustuva ymmärtäminen ei enää toimi, kontekstiin ja maailmantietoon perustuvat päättelystrategiat nousevat ymmärtämisessä entistäkin selvemmin esiin.

Analyysimme tulokset ovat samansuuntaisia aiempien suomen ja viron välistä ymmärrettävyyttä testaavien tutkimusten kanssa ja vahvistavat käsitystä siitä, että läheisten sukukielten välinen ymmärrettävyys perustuu pitkälti mutta ei ainoastaan kieltenväliseen samankaltaisuuteen. Suomen ja viron kontekstissa samankaltaisuus on ollut tutkimuksissa yleisin strategia, joka on tosin onnistuneiden käännöksien lisäksi välillä johtanut harhaan niin sanottujen petollisten ystävien eli toisiaan ulkoisesti muistuttavien mutta merkitykseltään erilaisten sanojen tapauksissa (Kaivapalu \& Muikku-Werner 2010: 83; Paajanen \& Muikku-Werner 2012: 237). Vironkielistä tekstiä kääntäneet ovat lisäksi maininneet ymmärtämistä edistävinä tekijöinä tukeutumisen muihin osattuihin kieliin (lähinnä englantiin), ääneen lukemisen, kielellisen pohjatiedon soveltamisen, lausekontekstin ja maailmantiedon hyödyntämisen, päättelykyvyn ja mielikuvituksen (Kaivapalu \& Muikku-Werner 2010: 
82-84; Muikku-Werner \& Heinonen 2012: 179; Paajanen \& MuikkuWerner 2012: 238-239).

Livvinkarjalan käännöstehtävässä muut kuin samankaltaisuuteen keskittyvät strategiat tuntuisivat nousevan esiin jopa selvemmin kuin tähänastisessa suomen ja viron välisessä tutkimuksessa. Yhtenä syynä voivat olla erilaiset tutkimusasetelmat ja etenkin erilaiset käännettävät tai luettavat tekstit. Suomen ja viron ymmärrettävyyden tutkimuksessa testimateriaalina on esimerkiksi ollut niin "aito" teksti (Terttu Nurron alun perin englanninkielisen tekstin käännökset Sild üle mere ja Silta meren yli) kuin lyhyt, sepitetty jouluaiheinen teksti. Alekseevan (2016) tutkimuksessa käännettävänä on ollut kaksi tekstiä: karjalanpiirakoiden valmistusresepti sekä karjalankielisestä Oma Mua -lehdestä otettu uutinen, joka kertoo Vienan Karjalassa pidetystä käsityökurssista. Kuten Alekseeva toteaa, karjalanpiirakkaresepti on ollut suomalaisille tuttu ja mahdollistanut kontekstitiedon hyödyntämisen, kun taas Venäjän Karjalaan sijoittuvan uutisen konteksti on ollut vaikeampi hahmottaa. Oman testimme livvinkarjalankielisen uutisen ominaispiirre on sen spesifi liittyminen Suomen ajankohtaiseen politiikkaan. Silloin kun opiskelija on tavoittanut uutisen sisällön (kilpailukykysopimuksen ja työajan pidentämisen), hän on voinut hyödyntää maailmantietoa ja tekstikontekstia monipuolisesti leksikaalisessa päättelyssä. Tämä tieto on auttanut päättelemään esimerkiksi eräiden venäläisten lainasanojen merkityksiä, mutta lisäksi kontekstitieto auttaa myös tunnistamaan karjalan ja suomen yhteisiä aineksia sellaisissa tapauksissa, joissa yhteistä alkuperää olevat sanat ovat kielissä erkaantuneet toisistaan.

Kaivapalu (2015: 68-69) on havainnut omassa suomen ja viron välistä ymmärrettävyyttä testaavassa tutkimuksessaan, että osallistujilla on kahdensuuntaisia samankaltaisuuteen ja kontekstiin liittyviä prosesseja. Osa osallistujista on lähtenyt ensisijaisesti liikkeelle suomen ja viron toisiaan muistuttavista sanoista ja pyrkinyt niiden perusteella selvittämään tekstin kontekstin. Toiset taas ovat toimineet päinvastaisella tavalla, eli he ovat pitäneet lähtökohtana kontekstia ja etsineet kontekstin tuella tekstistä sanoja, jotka olisivat samanlaisia kuin heidän 
äidinkielessään. Kaivapalu (mp.) esittää tulostensa perusteella mallin, jossa konteksti toimii eräänlaisena suodattimena: kieltenvälinen samankaltaisuus, metalingvistinen tieto ja yleistieto tarjoavat sanoille mahdollisia käännösvastineita, ja konteksti kontrolloi näiden vastineiden paikkansapitävyyttä. Livvinkarjalan käännöstehtävässä kontekstin ja maailmantiedon merkitys näyttäytyy erilaisena kuin tässä Kaivapalun mallissa. Niiden rooli ei rajoitu suodattimena toimimiseen, vaan ne ovat olennainen osa leksikaalisen päättelyn prosessia ja auttavat opiskelijoita tunnistamattomien sanojen merkitysten löytämisessä. Tekstikonteksti ja laajemmin siihen kytkeytyvä maailmantieto näyttävät olevan kokonaisvaltainen osa livvinkarjalan ymmärtämisprosessia.

Olemme kytkeneet tässä artikkelissa analyysimme reseptiivisen monikielisyyden viitekehykseen, mutta tuloksia voi luonnollisesti tarkastella myös kielenopetuksen näkökulmasta: sukukielisen tekstin kääntäminen voidaan rinnastaa vieraan kielen tekstin ymmärtämiseen ja sen opettamiseen. Kielenopetuksessa huomio keskittyy helposti lopputulokseen eli siihen, onko teksti ymmärretty oikein vain ei, ja vähemmälle jää sen pohtiminen, millaisin keinoin lopputulokseen on päästy. Opiskelijoiden livvinkarjalan käännöstehtävässä käyttämät ymmärtämisen ja leksikaalisen päättelyn keinot ovat hyvin samantapaisia kuin ne kielenoppimisen strategiat, jotka esimerkiksi Oxford (1990: 92-94) mainitsee niiden hallintaa käsittelevässä oppikirjassaan. On myös osoitettu, että ymmärtämistään tarkkailevat oppijat kykenevät ratkaisemaan tekstin sisällön selvittämisessä syntyvät ongelmat. Heillä on monia strategioita, joihin kuuluu muun muassa kontekstin hyödyntäminen. (Ks. esim. Bernhardt 1991; Vaurio 1998.) Voidaan ajatella, että kielenoppijan strategiseen kompetenssiin kuuluu kompensaatiostrategioita, jotka auttavat puuttuvan merkityksen avaamista hyödyntämällä muun muassa kontekstuaalisia vihjeitä tai arvaamista, sekä kognitiivisia strategioita, joihin kuuluvat deduktiivinen järkeily ja kontrastiivisen analyysin käyttö. (Ks. tarkemmin Oxford 1990: 9, 12.) Käytännön tasolla RM-tutkimuksen tuloksia onkin sovellettu sukukielten opetukseen (ks. esim. EuroCom-didaktiikasta Meißner 2002, seitsemän "siivilän" 
mallista Klein \& Stegmann 2000 sekä muista malleista Hufeisen \& Marx 2007: 315-318).

Ymmärtämisstrategioiden tiedostamisesta ja tietoisesta opettelusta on hyötyä sekä oppijoille että opettajille. Läheisen sukukielen opettelussa voidaan opettaa löytämään kieltenvälisiä samankaltaisuuksia, joiden tunnistaminen helpottuu metalingvistisen tiedon avulla. Samalla ei pidä kuitenkaan unohtaa tekstikontekstiin ja maailmantietoon nojautuvia strategioita, sillä useiden strategioiden samanaikainen käyttäminen johtaa tehokkaimpaan lopputulokseen. Kontekstin ja maailmantiedon huomioon ottaminen tarjoaa myös keinoja ratkaista tekstin sellaisia ongelmakohtia, joissa kieltenvälinen samankaltaisuus ei auta tai johtaa harhaan.

\section{Kiitokset}

Kiitämme Itä-Suomen yliopiston projektitutkijaa Natalia Giloevaa testiä varten luovutetusta livvinkarjalankielisestä tekstistä ja kahta anonyymia arvioijaa heidän kommenteistaan. Artikkeli liittyy Suomen Akatemian hankkeeseen SA 314848 .

\section{Lähteet}

Alekseeva, Irma 2016. Vienankarjalan ymmärtäminen suomen kielen pohjalta ['Understanding North Karelian on the basis of Finnish']. Pro gradu -tutkielma. Jyväskylä: Jyväskylän yliopisto. http://urn.fi/URN:NBN:fi:jyu201606203257

Anastasiou, Dimitris, Eleni Griva 2009. Awareness of reading strategy use and reading comprehension among poor and good readers. - IlköğretimOnline 8 (2), 283-297.

Babashamsi, Parastoo, Saeideh Bolandifar, Nahid Shakib 2013. Various models for reading comprehension process. - International Journal of Applied Linguistics \& English Literature 2 (6), 150-154. https://doi.org/10.7575/aiac. ijalel.v.2n.6p.150

Bernardini, Silvia 2001. Think-aloud protocols in translation research: Achievements, limits, future prospects. - Target: International Journal of Translation Studies 13 (2), 241-263. https://doi.org/10.1075/target.13.2.03ber 
Bernhardt, Elizabeth B. 1991. Reading Development in a Second Language. Theoretical, Empirical \& Classroom Perspectives. Norwood, NJ.: Ablex.

Boren, Ted M., Judith Ramey 2000. Thinking Aloud: Reconciling theory and practice. - IEEE Transactions on Professional Communication 43 (3), 261-278. https://doi.org/10.1109/47.867942

Heinonen, Maria 2015. “Koska virossa kaikki on nurinkurin”. Käännöstesti eräiden luettujen ja kuultujen vironkielisten sanojen ymmärtämisestä suomen kielen pohjalta [“'Because everything in Estonian is backwards” - A translation test of understanding certain read and listened Estonian words on the basis of Finnish language']. Pro gradu -tutkielma. Joensuu: Itä-Suomen yliopiosto. http://urn.fi/urn:nbn:fi:uef-20150086

Hufeisen, Britta, Nicole Marx 2007. How can DaFnE and EuroComGerm contribute to the concept of receptive multilingualism. - Jan D. ten Thije, Ludger Zeevaert (Eds.). Receptive Multilingualism. Linguistic Analyses, Language Policies and Dialectic Concepts. Hamburg Studies on Multilingualism 6. Amsterdam/Philadelphia: John Benjamins, 307-321. https:// doi.org/10.1075/hsm.6.20huf

Härmävaara, Hanna-Ilona 2013. Kielten samankaltaisuus monikielisen suomalais-virolaisen vuorovaikutuksen resurssina ['Cross-linguistic similarities as a resource of multilingual interaction between Finns and Estonians']. Lähivõrdlusi. Lähivertailuja 23, 60-88. https://doi.org/10.5128/LV23.03

Härmävaara, Hanna-Ilona 2014. Facilitating mutual understanding in everyday interaction between Finns and Estonians. - Applied Linguistics Review 5 (1), 211-245. https://doi.org/10.1515/applirev-2014-0010

Jääskeläinen Riitta 1999. Tapping the Process. An Explorative Study of the Cognitive and Affective Factors Involved in Translating. Joensuun Yliopiston humanistisia julkaisuja 22. Joensuu: University of Joensuu Press.

Kaivapalu, Annekatrin 2005. Lähdekieli kielenoppimisen apuna ['Contribution L1 to foreign language acquisition']. Jyväskylä Studies in Humanities 44. Jyväskylä: Jyväskylän yliopisto. http://urn.fi/URN:ISBN:951-39-2391-6

Kaivapalu, Annekatrin 2009. Vironkielisen suomenoppijan äidinkieli - ongelma, haaste vai voimavara? ['Estonian as the first language of a learner of Finnish: Problem, challenge or resource']. - Virittäjä 3, 382-402.

Kaivapalu, Annekatrin 2015. Eesti ja soome keele vastastikune mõistmine üksiksõna- ja tekstitasandil: lingvistilised tegurid, mõistmisprotsess ja sümmeetria ['Mutual intelligibility of Estonian and Finnish context-free words and texts: linguistic determinants, comprehension process and 
symmetry']. - Eesti Rakenduslingvistika Ühingu aastaraamat 11, 55-74. https://doi.org/10.5128/ERYa11.04

Kaivapalu, Annekatrin, Maisa Martin 2007. Morphology in transition: Plural inflection of Finnish nouns by Estonian and Russian learners. - Acta Linguistica Hungarica 54 (2), 129-156. https://doi.org/10.1556/ALing.54.2007.2.2

Kaivapalu, Annekatrin, Maisa Martin 2014. Symmetry of similarity: Definition, perception, measurement. Finnish and Estonian noun morphology as a testing ground. - Heli Paulasto, Lea Meriläinen, Helka Riionheimo, Maria Kok (Eds.). Language Contacts at the Crossroads of Disciplines. Cambridge: Cambridge Scholars Publishing, 283-318.

Kaivapalu, Annekatrin, Pirkko Muikku-Werner 2010. Reseptiivinen monikielisyys: miten suomenkielinen oppija ymmärtää viroa äidinkielensä pohjalta ['Receptive multilingualism: how Finnish as a first language helps learners to understand Estonian?']. - Lähivõrdlusi. Lähivertailuja 20, 68-97. https://doi.org/10.5128/LV20.03

Klein, Horst G., Tilbert D. Stegmann 2000. EuroComRom - Die sieben Siebe: Romanische Sprachen sofort lesen können. Aachen: Shaker Verlag.

Meißner, Franz-Joseph 2002. EuroComDidact. - Dorothea Rutke (Hrsg.). Europäische Mehrsprachigkeit. Analysen - Konzepte - Dokumente. Aachen: Shaker Verlag, 45-64.

Muikku-Werner, Pirkko 2013. Vironkielisen tekstin ymmärtäminen suomen kielen pohjalta ['Understanding Estonian texts on a Finnish language base']. - Lähivõrdlusi. Lähivertailuja 23, 210-237. https://doi.org/10.5128/ LV23.09

Muikku-Werner, Pirkko 2015. Tekstin semanttiset sidokset ja lähisukukielten ymmärrettävyys ['Semantic cohesion and the intelligibility of closely related languages']. - Lähivõrdlusi. Lähivertailuja 25, 191-216. https://doi. org/10.5128/LV25.08

Muikku-Werner, Pirkko 2016. Monitasoinen samankaltaisuus: virolaiset ja suomenkielisen tekstin ymmärtäminen ['Multidimensional similarity: Estonians and comprehension of Finnish text']. - Lähivõrdlusi. Lähivertailuja 26, 311-338. https://doi.org/10.5128/LV26.10

Muikku-Werner, Pirkko 2017. Lexical inferencing and the mutual intelligibility of Estonian and Finnish. - Nordic Journal of Linguistics 40 (2), 201-223. https://doi.org/10.1017/S0332586517000105

Muikku-Werner, Pirkko, Maria Heinonen 2012. Lumesadu - 'tarina' vai 'lumikasa' vai ei kumpikaan? Suomalaiset lukiolaiset viron sanoja tunnistamassa ['Lumesadu - 'tarina' or 'lumikasa' or something completely different? How 
Finnish senior high school students try to recognise Estonian words']. Lähivõrdlusi. Lähivertailuja 22, 157-187. https://doi.org/10.5128/LV22.06

Muikku-Werner, Pirkko, Helka Riionheimo 2018. Livvinkarjalaisen tekstin ymmärtäminen suomen pohjalta ['Understanding Olonets Karelian text on the basis of Finnish']. - Lähivõrdlusi. Lähivertailuja 28, 285-315. https://doi.org/10.5128/LV28.09

O’Malley, J. Michael, Anna U. Chamot 1990. Learning Strategies in Second Language Acquisition. New York: Cambridge University Press. https://doi. org/10.1017/CBO9781139524490

Oxford, Rebecca L. 1990. Language Learning Strategies. What Every Teacher Should Know. New York: Newbury House.

Oxford, Rebecca L. 2011. Teaching and Researching: Language Learning Strategies. N.Y: Harlow, England: Longman.

Paajanen, Ilona, Pirkko Muikku-Werner 2012. Tee on kitsas - onko 'tee kitkerää' vai oletteko 'te saita'? Suomalaiset opiskelijat viroa ymmärtämässä ['Tee on kitsas - is 'tea bitter' or are you 'penny-pinching'? Finnish students comprehending Estonian’]. - Lähivõrdlusi. Lähivertailuja 22, 219-258. https:// doi.org/10.5128/LV22.08

Rehbein, Jochen, Jan D. ten Thije, Anna Verschick 2012. Lingua receptiva (LaRa) - remarks on the quintessence of receptive multilingualism. International Journal of Bilingualism 16 (3), 248-264. https://doi. org/10.1177/1367006911426466

Ringbom, Håkan 2007. Cross-linguistic Similarity in Foreign Language Learning. Clevedon: Multilingual Matters. https://doi.org/10.21832/9781853599361

Tuomainen, Laura 2017. Vironkielisten sanojen ja sananmuotojen tulkinta tekstistä ilman viron opintoja ['The interpretation of Estonian words and word forms in text without studies in Estonian language']. Pro gradu -tutkielma. Joensuu: Itä-Suomen yliopisto. http://urn.fi/urn:nbn:fi:uef-20171029

van Bezooijen, Renée, Charlotte Gooskens 2007. Interlingual text comprehension: Linguistic and extralinguistic determinants. - Jan D. ten Thije, Ludger Zeevaert (Eds.). Receptive Multilingualism. Linguistic Analyses, Language Policies and Didactic Concepts. Hamburg Studies on Multilingualism 6. Amsterdam/Philadelphia: John Benjamins Publishing Company, 249-264. https://doi.org/10.1075/hsm.6.17bez

Vaurio, Leena 1998. Lexical Inferencing in Reading in English on the Secondary Level. Jyväskylä studies in education, psychology and social research 145. University of Jyväskylä. 
Zeevaert, Ludger, Jan D. ten Thije 2007. Introduction. - Jan D. ten Thije, Ludger Zeevaert (Eds.). Receptive Multilingualism. Linguistic Analyses, Language Policies and Didactic Concepts. Hamburg Studies on Multilingualism 6. Amsterdam/Philadelphia: John Benjamins Publishing Company, 1-21. https://doi.org/10.1075/hsm.6.02zee

\section{Pirkko Muikku-Werner}

Itä-Suomen yliopiston humanistinen osasto. Suomen kieli ja kulttuuritieteet PL 111, FI-80101 Joensuu Finland

pirkko.muikku-werner@uef.fi

\section{Helka Riionheimo}

Itä-Suomen yliopiston humanistinen osasto. Suomen kieli ja kulttuuritieteet PL 111, FI-80101 Joensuu Finland

helka.riionheimo@uef.fi 


\section{Liite 1. Käännöstestin teksti kokonaisuudessaan sekä sen melko sanatarkka suomennos}

Lihavoinnilla osoitettu se virke, jonka käännöksiä artikkelissa tarkastellaan.

Juuvan kunnan ideju käyttiä ruadajien ruadoaijan pitkendämisty liikundah on viritännyh suurdu valdukunnallistu kiinnostustu. Täh idejah näh on taratettu ezimerkikse Twitteras. Juuvan kunnanjohtai Markus Hirvonen sanelou, gu häneh ollah otettu yhtevytty piäl 20 (kahtenkymmenen) kunnanjohtajan. Kilbumaltosobimuksen mugah päivän ruadoaigu roih kuuttu minuuttua pitkembi, da muga ruadonedäli roih puoldu čuassuu pitkembi. Tädä Juuvan kunnan johtojoukon mugah pidäy käyttiä ruadajien hyvinvoindah niškoi. Yhtehizel liikunduaigua voibi kävellä pihal, kižata slonamiäččyh libo čurata mäis. Juuvan mugah liikundu ennepäiestäy taudiloi da vähendäy kois olendua voimattomuksien täh. Kunduruavonandajat juohattau, gu liikundu ei kuulu ruadoaigah. Juuga uskou, gu toizetgi ellendetäh sen ehoituksen. (Yle uudizet karjalakse 11.11.2016.)

Juuan kunnan idea käyttää työntekijöiden työajan pidennystä liikuntaan on herättänyt suurta valtakunnallista kiinnostusta. Ideasta on keskusteltu esimerkiksi Twitterissä. Juuan kunnanjohtaja Markus Hirvonen kertoo, että häneen on ottanut yhteyttä yli 20 kunnanjohtajaa. Kilpailukykysopimuksen mukaan päivän työajasta tulee kuusi minuuttia pitempi ja työviikosta puoli tuntia pitempi. Tätä pitää Juuan kunnan johtoryhmän mukaan käyttää työntekijöiden hyvinvointiin. Yhteisellä liikunta-ajalla voi kävellä pihalla, pelata norsupalloa tai laskea mäkeä. Juuan kunnan mukaan liikunta ennaltaehkäisee sairauksia ja vähentää poissa olemista sairauksien vuoksi. Kuntatyönantajat muistuttaa, että liikunta ei kuulu työaikaan. Juuka uskoo, että muutkin ymmärtävät sen ehdotuksen. [Käännös Helka Riionheimo.] 


\section{Liite 2. Perusteluissa mainitut ymmärtämisstrategiat henkilöittäin}

$\mathrm{x}=$ strategiaan viitattu käännöstä auttavana keinona, $\mathrm{z}=$ strategiaan viitattu vastauksessa ainoastaan epäonnistuneena keinona. Opiskelijat on järjestetty strategioiden lukumäärän mukaan.

\begin{tabular}{|c|c|c|c|c|c|c|c|c|c|}
\hline $\begin{array}{c}\text { Opis- } \\
\text { kelija }\end{array}$ & $\begin{array}{c}\text { Saman- } \\
\text { kalt. }\end{array}$ & $\begin{array}{c}\text { Muut } \\
\text { kielet }\end{array}$ & $\begin{array}{c}\text { Ääneen } \\
\text { luk. }\end{array}$ & $\begin{array}{c}\text { Meta- } \\
\text { lingv. }\end{array}$ & $\begin{array}{c}\text { Virke- } \\
\text { kont. }\end{array}$ & $\begin{array}{c}\text { Teksti- } \\
\text { kont. }\end{array}$ & $\begin{array}{c}\text { Maail- } \\
\text { mant. }\end{array}$ & “Päätt." “Arv.” \\
\hline O17 & $\mathrm{x}$ & $\mathrm{x}$ & & $\mathrm{x}$ & $\mathrm{x}$ & & $\mathrm{x}$ & $\mathrm{x}$ & \\
\hline O5 & $\mathrm{x}$ & & $\mathrm{x}$ & $\mathrm{x}$ & & & $\mathrm{x}$ & $\mathrm{x}$ & \\
\hline O16 & $\mathrm{x}$ & $\mathrm{x}$ & & & & $\mathrm{x}$ & $\mathrm{x}$ & & \\
\hline O42 & $\mathrm{x}$ & $\mathrm{x}$ & $\mathrm{x}$ & & & & $\mathrm{x}$ & & \\
\hline O60 & $\mathrm{x}$ & & & $\mathrm{x}$ & & $\mathrm{x}$ & & $\mathrm{x}$ & \\
\hline O18 & $\mathrm{x}$ & & & $\mathrm{x}$ & & $\mathrm{x}$ & & & \\
\hline O19 & $\mathrm{x}$ & & & $\mathrm{x}$ & & $\mathrm{x}$ & & & \\
\hline O20 & $\mathrm{x}$ & & $\mathrm{x}$ & & & $\mathrm{x}$ & & & \\
\hline O23 & $\mathrm{x}$ & & & & $\mathrm{x}$ & $\mathrm{x}$ & & & \\
\hline O43 & $\mathrm{x}$ & $\mathrm{x}$ & & $\mathrm{x}$ & & & & & \\
\hline O44 & $\mathrm{x}$ & & & & & $\mathrm{x}$ & $\mathrm{x}$ & & \\
\hline O57 & $\mathrm{x}$ & & & $\mathrm{x}$ & & $\mathrm{x}$ & & & \\
\hline O8 & $\mathrm{x}$ & & & & & $\mathrm{x}$ & & & $\mathrm{x}$ \\
\hline O1 & & & & & & & $\mathrm{x}$ & & $\mathrm{x}$ \\
\hline O12 & $\mathrm{x}$ & & & & & & $\mathrm{x}$ & & \\
\hline O25 & & & $\mathrm{x}$ & & $\mathrm{x}$ & & & & \\
\hline O26 & $\mathrm{x}$ & & & $\mathrm{x}$ & & & & & \\
\hline O27 & $\mathrm{x}$ & & & & & & & & $\mathrm{x}$ \\
\hline O29 & & & & & & $\mathrm{x}$ & $\mathrm{x}$ & & \\
\hline O3 & $\mathrm{x}$ & & & & & $\mathrm{x}$ & & & \\
\hline O33 & $\mathrm{x}$ & & & & & & & & $\mathrm{x}$ \\
\hline O35 & $\mathrm{x}$ & & & & & & & & $\mathrm{x}$ \\
\hline O38 & $\mathrm{x}$ & & & & & $\mathrm{x}$ & & & \\
\hline O40 & $\mathrm{x}$ & & & & & & $\mathrm{x}$ & & \\
\hline O46 & $\mathrm{x}$ & & & & & $\mathrm{x}$ & & & \\
\hline O47 & $\mathrm{x}$ & & & & & & $\mathrm{x}$ & & \\
\hline O53 & $\mathrm{x}$ & & & & & & & & \\
\hline
\end{tabular}


LIVVINKARJALAN YMMÄRTÄMISEN STRATEGIOITA

\begin{tabular}{|c|c|c|c|c|c|c|c|c|c|}
\hline $\begin{array}{l}\text { Opis- } \\
\text { kelija }\end{array}$ & $\begin{array}{c}\text { Saman- } \\
\text { kalt. }\end{array}$ & $\begin{array}{l}\text { Muut } \\
\text { kielet }\end{array}$ & $\begin{array}{c}\text { Ääneen } \\
\text { luk. }\end{array}$ & $\begin{array}{l}\text { Meta- } \\
\text { lingv. }\end{array}$ & $\begin{array}{l}\text { Virke- } \\
\text { kont. }\end{array}$ & $\begin{array}{l}\text { Teksti- } \\
\text { kont. }\end{array}$ & $\begin{array}{l}\text { Maail- } \\
\text { mant. }\end{array}$ & "Päätt." & "Arv." \\
\hline O6 & $\mathrm{z}$ & & & & & & $\mathrm{x}$ & & \\
\hline O7 & $\mathrm{z}$ & & & & & $\mathrm{x}$ & & & \\
\hline O10 & $\mathrm{x}$ & & & & & & & & \\
\hline O13 & & & & & $\mathrm{x}$ & & & & \\
\hline $\mathrm{O} 2$ & & & $\mathrm{x}$ & & & & & & \\
\hline $\mathrm{O} 21$ & & & & & & & $\mathrm{x}$ & & \\
\hline $\mathrm{O} 22$ & $\mathrm{x}$ & & & & & & & & \\
\hline O30 & & & & & & & & & $\mathrm{x}$ \\
\hline O31 & & & $\mathrm{x}$ & & & & & & \\
\hline O32 & $\mathrm{x}$ & & & & & & & & \\
\hline O34 & & & & & & $\mathrm{x}$ & & & \\
\hline O36 & & & & & & & & & $\mathrm{x}$ \\
\hline O37 & & & & & & & & & $\mathrm{x}$ \\
\hline $\mathrm{O} 4$ & $x$ & & & & & & & & \\
\hline O41 & & & & & & & & $\mathrm{x}$ & \\
\hline O45 & & & & & & & & & $\mathrm{x}$ \\
\hline $\mathrm{O} 48$ & $\mathrm{x}$ & & & & & & & & \\
\hline O49 & $x$ & & & & & & & & \\
\hline O51 & & & & & & $\mathrm{x}$ & & & \\
\hline O52 & & & & & & & $\mathrm{x}$ & & \\
\hline O54 & & & & & & & & & $\mathrm{x}$ \\
\hline O59 & & & & & & $\mathrm{x}$ & & & \\
\hline O9 & $\mathrm{x}$ & & & & & & & & \\
\hline \multicolumn{10}{|l|}{ O11 } \\
\hline \multicolumn{10}{|l|}{ O14 } \\
\hline \multicolumn{10}{|l|}{ O15 } \\
\hline \multicolumn{10}{|l|}{ O24 } \\
\hline \multicolumn{10}{|l|}{$\mathrm{O} 28$} \\
\hline \multicolumn{10}{|l|}{ O39 } \\
\hline \multicolumn{10}{|l|}{ O55 } \\
\hline \multicolumn{10}{|l|}{ O56 } \\
\hline \multicolumn{10}{|l|}{ O58 } \\
\hline O50 & & & & & & & & & \\
\hline
\end{tabular}




\title{
Strategies in Olonets Karelian text comprehension
}

\author{
PIRKKO MUIKKU-WERNER, \\ HELKA RIIONHEIMO \\ University of Eastern Finland
}

Research on receptive multilingualism has, in the context of several language families, shown that when a reader meets with a text written in a closely related language, comprehension starts with recognizing words that bear resemblance to his/her mother tongue. However, even cognate languages have developed differently and may have, for example, adopted loan words from different sources. Consequently, relying on similarities is not sufficient enough to understand the whole meaning of the text but other kind of inferencing is needed as well. In the present article, the authors examine the cognitive strategies employed by 60 Finnish-speaking students when translating an Olonets Karelian text into Finnish. The article focuses on a specific sentence that is difficult to understand because of a few Russian loan words.

The students have translated the text into Finnish and described their translation process, thus offering a possibility to investigate the consciously used understanding strategies. The analysis shows that the students have relayed on the similar vocabulary of Karelian and Finnish and on metalinguistic knowledge. Furthermore, they have taken the textual context as well as general knowledge into consideration. Different strategies seem to work in parallel and support each other.

The results are compared with earlier studies on mutual understanding of Finnish and Estonian. In addition, the practical applicability of the results is considered: would it be beneficial to teach understanding and inferencing strategies to the learners of a related language?

Keywords: receptive multilingualism; language relatedness; translating; lexical inferencing 